\title{
Juxtaglomerular Cell Tumor
}

National Cancer Institute

\section{Source}

National Cancer Institute. Juxtaglomerular Cell Tumor. NCI Thesaurus. Code C4162.

A benign, well circumscribed neoplasm arising from the cortex of the kidney. It secrets renin and the patients usually present with severe hypertension and marked hypokalemia. Morphologically, it is characterized by the presence of sheets of polygonal or spindleshaped neoplastic cells forming a hemangiopericytic pattern. 